\title{
Screening Pepper Cultivars for Resistance to Flower Abscission: A Comparison of Techniques
}

\author{
H.C. Wien ${ }^{1}$ \\ Department of Fruit and Vegetable Science, Cornell University, Ithaca, \\ NY 14853 \\ Additional index words. ethephon, flower buds, low-light stress, pedicel abscission, \\ Capsicum annuum
}

\begin{abstract}
In one greenhouse and two field experiments, eight or ten pepper (Capsicum annuum $\mathbf{L}$.) cultivars were subjected to low-light stress by use of shade cloth (reducing light by $80 \%$ ) or to foliar sprays of ethephon at 75 or 150 pi-liter-]. Both low-light stress and ethephon identified 'Ace',' Canape', and. 'Belrubi' as less susceptible to flower and flower bud abscission than other cultivars in the first field experiment. In the 2 nd year, air mean maxima of $32 \mathrm{C}$ caused severe abscission in controls and shaded plants, and complete loss of flowers in those sprayed with ethephon. Abscission of disbudded pedicels was not related to abscission susceptibility of eight cultivars when subjected to shade. While ethephon spray can serve as a satisfactory abscission screening tool under unstressed growing conditions, low-light stress imposed by shading may be used under a wider range of conditions. Chemical name used: 2-chloroethyl phosphoric acid (ethephon).
\end{abstract}

Ethephon foliar spray at the preanthesis stage has been used to identify pepper cultivars with relatively low susceptibility to

Received for publication 30 Nov. 1989. Vegetable Crops Paper no. 885. The partial support of this research by Agway Inc., Petoseed Co., and by Federal Hatch Act funds (Project no NYC-161425, USDA) is gratefully acknowledged. The cost of publishing this paper was defrayed in part by the payment of page charges. Under postal regulations, this paper therefore must be hereby marked advertisement solely to indicate this fact. ${ }^{1}$ Associate Professor. stress-induced flower and flower bud abscission (Tripp and Wien, 1989). The screening technique is based on the finding that flower bud abscission is mediated by ethylene (Wien et al., 1989a). Given the variation in ethephon uptake and activity with changes in temperature (Kays and Beaudry, 1987), the reliability of the technique may vary with environmental conditions. Direct imposition of heat stress may prove complicated and expensive, involving construction of heated structures in the field (Nielson and Hall, 1985), or use of temperature-controlled greenhouses (Stoner and Otto, 1975). Recent 
Table 1. Effect of ethephon foliar spray or 1 week of $80 \%$ shade on abscission of flowers and flower buds on four flowering nodes of eight pepper cultivars (Expt. 1).

\begin{tabular}{lllll}
\hline \hline & \multicolumn{4}{c}{ Abscission $(\%)^{2}$} \\
\cline { 2 - 4 } Cultivar & 0 & 75 & 150 & $\begin{array}{c}80 \% \\
\text { shading }\end{array}$ \\
\cline { 2 - 5 } Ethephon & $\left(\mu \cdot 1 \cdot\right.$ liter $\left.^{-1}\right)$ & \\
Ace & $4 \mathrm{a}$ & $38 \mathrm{a}$ & $58 \mathrm{a}$ & $39 \mathrm{a}$ \\
Canape & $20 \mathrm{ab}$ & $40 \mathrm{ab}$ & $63 \mathrm{ab}$ & $48 \mathrm{ab}$ \\
Belrubi & $33 \mathrm{~b}$ & $47 \mathrm{ab}$ & $66 \mathrm{ab}$ & $49 \mathrm{ab}$ \\
Lady Bell & $15 \mathrm{ab}$ & $42 \mathrm{ab}$ & $74 \mathrm{ab}$ & $42 \mathrm{ab}$ \\
Green Boy & $28 \mathrm{~b}$ & $67 \mathrm{ab}$ & $77 \mathrm{ab}$ & $67 \mathrm{abc}$ \\
Big Bertha & $26 \mathrm{ab}$ & $67 \mathrm{ab}$ & $75 \mathrm{ab}$ & $69 \mathrm{bc}$ \\
E. Calwonder & $32 \mathrm{~b}$ & $70 \mathrm{~b}$ & $86 \mathrm{~b}$ & $81 \mathrm{c}$ \\
Shamrock & $29 \mathrm{~b}$ & $70 \mathrm{~b}$ & $88 \mathrm{~b}$ & $87 \mathrm{c}$ \\
\hline
\end{tabular}

${ }^{2}$ Effects of treatments, cultivars, and their interaction significant at $P=0.01$. Means within columns followed by different letters are significantly different at $P=0.05$ as determined by HSD values of the arcsin-transformed percentage data.

Table 2. Effect of 10 days of $80 \%$ shade on abscission of flowers and flower buds from nodes 1 and 2 of 10 pepper cultivars (Expt. 2).

\begin{tabular}{lcc}
\hline \hline & \multicolumn{2}{c}{ Abscission $(\%)^{\mathrm{z}}$} \\
\cline { 2 - 3 } Cultivar & \multicolumn{2}{c}{ Shade (\%) } \\
\cline { 2 - 3 } Ace & $41 \mathrm{a}$ & 80 \\
Lady Bell & $79 \mathrm{~b}$ & $46 \mathrm{a}$ \\
Wonder Bell & $89 \mathrm{~b}$ & $70 \mathrm{ab}$ \\
Bell Star & $93 \mathrm{~b}$ & $94 \mathrm{~b}$ \\
Bell Tower & $97 \mathrm{~b}$ & $98 \mathrm{~b}$ \\
Cadice & $96 \mathrm{~b}$ & $96 \mathrm{~b}$ \\
Bell Captain & $98 \mathrm{~b}$ & $98 \mathrm{~b}$ \\
Sweet Belle & $98 \mathrm{~b}$ & $98 \mathrm{~b}$ \\
Jupiter & $99 \mathrm{~b}$ & $98 \mathrm{~b}$ \\
Shamrock & $100 \mathrm{~b}$ & $99 \mathrm{~b}$ \\
\hline
\end{tabular}

${ }^{2}$ Effect of shade not significant. Means within columns followed by different letters are significantly different at $P=0.05$ as determined by HSD values of the arcsin-transformed percentage data.

research indicated that pepper cultivars susceptible to heat stress-induced abscission also showed increased abscission in heavy shade (Wien et al., 1989a). In other experiments, flower bud removal resulted in rapid abscission of all pedicels of stress-susceptible 'Shamrock', while some pedicels of resistant 'Ace' were retained. The present experiments were conducted to determine if shading or bud removal could serve as improved

Table 3. Abscission of flowers and flower buds from eight bell pepper cultivars as a result of shade treatment, compared to pedicel stub abscission after bud removal.

\section{Abscission $(\%)^{2}$}

\begin{tabular}{|c|c|c|c|c|}
\hline \multirow[b]{3}{*}{ Cultivar } & \multirow{3}{*}{ Control $^{y}$} & \multirow[b]{3}{*}{$\begin{array}{c}\text { Pedicel }^{y} \\
\text { stub }\end{array}$} & \multirow{2}{*}{\multicolumn{2}{|c|}{$80 \%$ shade }} \\
\hline & & & & \\
\hline & & & $\begin{array}{c}\text { Tagged } \\
\text { nodes }\end{array}$ & $\begin{array}{c}\text { Nodes }^{x} \\
\text { above }\end{array}$ \\
\hline Ace & $6 \pm 10$ & $66 \pm 28$ & $48 \pm 32$ & $28 \pm 16$ \\
\hline Canape. & 0 & $97 \pm 8$ & $28 \pm 23$ & $26 \pm 13$ \\
\hline Belrubi & 0 & 100 & $37 \pm 14$ & $12 \pm 12$ \\
\hline Lady Bell & $3 \pm 8$ & $88 \pm 16$ & $83 \pm 24$ & $52 \pm 14$ \\
\hline Green Boy & 0 & $88 \pm 16$ & $88 \pm 11$ & $68 \pm 18$ \\
\hline Big Bertha & 0 & 100 & $86 \pm 19$ & $60 \pm 23$ \\
\hline E. Calwonder & $6 \pm 10$ & $83 \pm 29$ & $94 \pm 10$ & $59 \pm 15$ \\
\hline Shamrock & $6 \pm 10$ & 100 & $66 \pm 38$ & $59 \pm 26$ \\
\hline
\end{tabular}

${ }^{2}$ Mean \pm standard error. Abscission data taken 1 week after end of a l-week $80 \%$ shade treatment.

${ }^{y} r$ (tagged nodes vs. pedicel stub abscission $)=-0.09 \mathrm{~ns}$.

${ }^{x}$ Abscission of buds from three higher nodes on the same branch as the tagged node.
Four weeks after seeds were sown in styrofoam transplant trays, seedlings were transplanted into peat-vermiculite soilless mix in 40 polyethylene pots. To achieve simultaneous flowering, seeds of the late-flowering 'Shamrock', 'Big Bertha', and 'Early Calwonder' were sown 1 week ahead of the other five cultivars. The same eight cultivars compared in Expt. 1 were each subjected to one of the following treatments, beginning when buds at branching level 5 were 5 to $8 \mathrm{~mm}$ in diameter (63 and 56 DAT for late and early cultivars, respectively): 1) Control, not treated; 2) removal of five buds (5 to $8 \mathrm{~mm}$ diameter) per plant, leaving a $1-\mathrm{cm}$ pedicel stub; or 3) shading the plants for 7 days with a canopy of polypropylene shade fabric $(80 \%$ shade). In treatments 1 and 3 , observations were made daily, beginning at bud removal on five tagged buds of 5- to 8-mm diameter, found at branching levels 5 or 6 . One week after the end of the shade treatment, abscission was determined at these nodes and at three nodes above the tagged node. There were seven pots per cultivar per treatment, arranged in a completely random design on the greenhouse bench before and after shade treatment. In all experiments, statistical analysis was performed on the arcsin-transformed percentage abscission data (Tripp and Wien, 1989).

The results of Expt. 1 confirmed the findings of Tripp and Wien (1989) that ethephon foliar spray can identify pepper cultivars that are least susceptible to stress with regard to flower bud abscission (Table 1). As in the earlier work, 'Ace' and 'Canape' showed less abscission than 'Shamrock' and 'Big Bertha'. The same range of susceptibilities occurred in the present experiment when plants were subjected to 7 days of $80 \%$ shade. Abscission in the unshaded control plants was moderate, and not well-correlated with abscission under low-light stress or ethephon spray.

In Expt. 2, there was virtually complete flower and flower bud abscission in eight of the 10 cultivars, even in unshaded controls (Table 2). The period of treatment coincided with record high temperatures in the field, with mean maxima averaging $32 \mathrm{C}$ for the first week of shading; 4C higher than the equivalent period in Expt. 1. Minima were 16 and $15 \mathrm{C}$ in Expts. 1 and 2, respectively. Only 'Ace' showed significantly less abscission than the others under these conditions, with 'Lady Bell' giving an intermediate response. The shade treatment did not further accentuate abscission of these cultivars. All cultivars showed complete flower and flower bud abscission with both ethephon spray treatments. The release of ethylene from ethephon and ethephon uptake by plant tissue are enhanced by high temperature (Kays and Beaudry, 1987). When combined with the direct stress effect of the temperature, which presumably also caused ethylene production by the plant (Wien et al., 1989a), the total ethylene generated apparently was sufficient to cause complete abscission in even resistant 'Ace'. Tripp and Wien (1989) found in some ethephon foliar spray experiments 
that 200 to $300 \mu \mathrm{l}$ ethephon/liter brought about total flower and flower bud loss in all pepper cultivars tested. Phytotoxic effects of ethephon on other crops have been associated with use of normally optimal concentrations under high temperature conditions (Flore and Bukovac, 1982).

In the pedicel abscission experiment, pedicel stub abscission was not well-correlated with abscission rate under low light (Table 3). Although 'Ace' showed less pedicel abscission than 'Shamrock', the stress abscission-resistant cultivars Canape and Belrubi had high rates of pedicel abscission. Retention of the pedicel stub after bud removal probably means that the pedicel is producing sufficient auxin to prevent formation of an abscission layer (Wien et al., 1989a). Abscission resistance of intact flowers and flower buds under stress appears not to be related to pedicel auxin content of nonstressed plants.

As in previous experiments, low-light stress produced less abscission in 'Ace', 'Canape', and 'Belrubi' than in the other five cultivars (compare Tables 3 and 1). 'Ace' and 'Canape' also were least susceptible to heat stressinduced abscission (Wien et al., 1989b). Low light conditions are more readily imposed under field conditions than high temperature. With shade-fabric row covers or larger enclosures, light levels can be uniformly reduced over large areas without substantial changes in air temperatures (Wien et al., 1989a). High temperature screening in temperate climates requires good temperature control in greenhouses (Stoner and Otto, 1975), or field tunnels with artificial heat, imposed during the night (Nielson and Hall, 1985). During the day, such tunnels require ventilation or removal to prevent excessive heat. The ethephon foliar spray technique (Tripp and Wien, 1989) worked well under conditions of good growth in Expt. 1, but resulted in excess abscission under the higher temperatures of Expt. 2. The technique is thus only useful when climatic conditions during the immediate pre-bloom period can be predicted to be optimal for pepper growth and fruit set.

\section{Literature Cited}

Flore, J.A. and M.J. Bukovac. 1982. Factors influencing" absorption of ${ }^{14} \mathrm{C}$ (2-chloroethyl)phosphonic acid by leaves of cherry. J. Amer. Soc. Hort. Sci. 107:965-968.

Kays, S.J. and R.M. Beaudry. 1987. Techniques for inducing ethylene effects. Acta. Hort. 201:77-116.

Nielsen, C.L. and A.E. Hall. 1985. Responses of cowpea (Vigna unguiculata L. Walp.) in the field to high night air temperature during flowering: II. Plant response. Field Crops Res. 10:181-196.

Stoner, A.K. and B.E. Otto. 1975. A greenhouse method to evaluate high temperature setting ability in the Tomato. HortScience 10:264-265.

Tripp, K.E. and H.C. Wien. 1989. Screening with ethephon for abscission resistance of flower buds in bell pepper. HortScience 24:655-657.

Wien, H.C., A.D. Turner, and S.F. Yang. 1989a. Hormonal basis for low light intensity-induced flower bud abscission of pepper. J. Amer. Soc. Hort. Sci. 114:981-985. and A. D. Turner. 1989b. Abscission of reproductive structures in pepper: Causes, mecha- nisms and control, p. 150-165. In: S.K. Green bed.). Tomato and pepper production in the tropics. Tainan, Taiwan. 